Jarosław Wołkonowski

Uniwersytet w Białymstoku e-mail: wolkonowski@uwb.edu.pl telefon: +48 857457153

DOI: $10.15290 / \mathrm{mhi} \cdot 2015.14 .02 .20$

\title{
Niektóre polityczno-prawne aspekty pokojowej umowy między Litwą i Rosją z 12 lipca $1920 \mathrm{r}$.
}

\begin{abstract}
SUMMARY
Some Political and Legal Aspects of the Peace Treaty between Russia and Lithuania from 12th of July 1920
\end{abstract}

The paper analyzes selected political and legal issues of the peace treaty between Lithuania and Bolshevik Russia from 12 July 1920. The treaty had its secret part, which consisted of a few attachments, signed by the representatives of both parties. The most important protocol concerned the neutrality of Lithuania during the Polish - Bolshevik war. Lithuania gave permission for the Bolsheviks to use Lithuanian territory for strategic war purposes of the Red Army against Poland. None of these attachments were presented for ratification by the Lithuanian parliament. Speeches presented by Lithuanian MPs indicate that none of them knew about the secret attachments. The Prime Minister and Foreign Minister did not inform MPs of their existence. The treaty was ratified on August 6, 1920. During the debate MPs of the Lithuanian parliament unambiguously supported Bolshevik Russia in its fight against the Polish army. They wrongfully understood the intentions of the Bolsheviks.

Key words: Polish-Bolshevik war 1920, secret attachments to the Lithuanian-Bolshevik peace treaty from July 12, 1920, neutrality of Lithuania, ratification

Słowa kluczowe: wojna polsko-bolszewicka 1920, tajne załączniki umowy pokojowej między Litwą i Rosyjską Socjalistyczną Federacyjną Republiką Radziecką z 12 lipca 1920 r., neutralność Litwy, ratyfikacja

\section{Pierwsze artykuły umowy}

W maju 1920 r. rozpoczęły się spotkania przedstawicieli rządów Litwy i Rosji, które miały na celu przygotowanie umowy pokojowej ${ }^{1}$ regulującej obu-

1 P. Łossowski, Konflikt polsko-litewski 1918-1920, Warszawa 1996, s. 112. 
stronnie ważne i sporne kwestie. Strona litewska do tych rozmów zgłosiła pięciu przedstawicieli mających niezbędne pełnomocnictwa. Byli to: Tomas Naruševičius, Petras Klimas, Simanas Rozenbaumas, Juozas Vailokaitis i Vytautas Račkauskas. Ze strony Rosyjskiej Federacyjnej Socjalistycznej Republiki Radzieckiej stosowne pełnomocnictwa otrzymali następujący przedstawiciele: Adolf Joffe, Julian Marchlewski i Leonid Obolenski.

5 czerwca 1920 r. odbyło się posiedzenie najwyższych władz Litwy i delegacji na rozmowy ze stroną rosyjską dotyczące przyszłej litewsko-rosyjskiej umowy pokojowej zwanej Memorandum, które nakreśliło ogólne punkty przyszłej umowy jawnej i umowy tajnej².

Obie delegacje podczas spotkań w Moskwie wypracowały i uzgodniły tekst umowy (z dwiema mapami), którą ostatecznie podpisały 12 lipca $1920 \mathrm{r}$. Następnie, 6 sierpnia 1920 r., tekst umowy został ratyfikowany przez Sejm Litwy w obecności 88 posłów, przy 3 głosach wstrzymujących się 3 . Odpowiednie kroki poczyniła w tym kierunku również Rosja. Oddzielnie do poszczególnych punktów umowy obie delegacje podpisały stosowne porozumienia, stanowiące część tajną, które zawierały szczegółowe rozwiązania i wyjaśnienia uzupełniające wymienioną umowę.

We wstępie umowy stwierdzano, że obie strony, mając na celu dobrosąsiedzkie stosunki między obu państwami oparte na zasadach prawa i sprawiedliwości, wyznaczyły swych przedstawicieli (wyżej wymienionych) do prowadzenia negocjacji.

W artykule I Rosyjska Federacyjna Socjalistyczna Republika Radziecka uznaje suwerenność i niepodległość Litwy oraz zrzeka się po wsze czasy wszelkich praw, jakie miała Rosja względem narodu Litwy i jego terytorium ${ }^{4}$.

W kolejnym artykule umowy precyzyjnie określono przyszłą granicę między Litwą a Rosją na dzień podpisania umowy. Przebiegała ona wzdłuż linii miast od północy, pozostawiając po stronie litewskiej Brasław, Mołodeczno, Lidę, dalej wzdłuż rzeki Niemen, którą przecinała na wysokości kilkudziesięciu kilometrów na południe od Grodna i kończyła się w punkcie, gdzie rzeka Gorodnianka wpada do Biebrzy5. Należy odnotować, że większość tych terytoriów (jako ziemia wileńska i województwo białostockie) wiosną 1919 r. włączono do

2 Lietuvos Centrinis Valstybès Archyvas (dalej: LCVA), Fondas (zespół, dalej: F.) 383, Apyrašas (opis dalej Ap.) 7, Byla (teczka dalej: B.) 77, s. 165-168.

3 Stenogram 36 posiedzenia Sejmu Ustawodawczego Litwy w dniu 6 sierpnia 1920 roku, http:// www3.lrs.lt/pls/inter_archyvas/dokpaieska_arch.showdoc_l?p_id=113702\&p_query=Lietuvos $\% 20$ i\%20Rusijos\%20taikos\%20sutartis\&p tr2=2 (03.01.2015).

4 http://www3.lrs.lt/pls/inter_archyvas/dokpaieska_arch.showdoc_l?p_id=112582\&p_query=taikos $\% 20$ sutartis\&p_tr2=2 (03.01.2015).

5 Stenogram posiedzenia Sejmu Republiki Litewskiej z dnia 6 sierpnia 1920 roku, I sesji, 36 posiedzenia http://www3.lrs.lt/pls/inter_archyvas/dokpaieska_arch.showdoc_l?p_id=113702\&p_query=Li etuvos $\% 20 \mathrm{i} \% 20$ Rusijos\%20taikos\%20sutartis\&p.r2=2 (03.01.2015). 
państwa polskiego. Wiosną i latem 1919 r. odbyły się tu wybory samorządowe i rozpoczęła funkcjonowanie administracja polska. Do artykułu II strona litewska podczas ratyfikacji zgłosiła cztery uwagi: pierwsza z nich dotyczyła podpisania przez Litwę umów z Polską i Łotwą o granicy z tymi państwami, druga - sposobu delimitacji granicy litewsko-rosyjskiej, a także określenia granicy przebiegającej przez zbiorniki wodne, trzecia - rozbieżności w zakresie przebiegu granicy pomiędzy tekstem umowy a mapami załączonymi do tej umowy i przyznania pierwszeństwa $\mathrm{w}$ takim przypadku tekstowi umowy, czwarta zakazu upustu wody ze zbiorników wodnych znajdujących się na granicy litewsko-rosyjskiej6.

Kwestie związane z odprawami celnymi i strażą graniczną przedstawione $\mathrm{w}$ artykule III miały być uregulowane $\mathrm{w}$ odrębnej umowie litewsko-rosyjskiej po "wyzwoleniu i oswobodzeniu tych terenów spod okupacji”, co miało oznaczać wyparcie Polski z terenów położonych po obu stronach przyszłej granicy litewsko-rosyjskiej.

W artykule IV umowy obie strony reprezentowały stanowisko wykluczające powołanie na swych terenach rządów i organizacji państw znajdujących się $\mathrm{w}$ stanie wojny $\mathrm{z}$ drugą umawiającą się stroną ${ }^{7}$.

\section{Neutralność Litwy}

Bardzo ważny był kolejny artykuł umowy stwierdzający, że Litwa ogłasza neutralność, Rosja zaś ze swej strony zobowiązuje się to uhonorować i uczestniczyć w gwarancjach przestrzegania tej neutralności. W sprawie realizacji tego punktu zostały podpisane odrębne tajne rosyjskie i litewskie porozumienia, których tekst był następujący:

R.S.F.R.R. Delegacja ds. rozmów na temat umowy pokojowej z Litwą 12 lipca 1920 roku Moskwa

Odnośnie do artykułu V

Do litewskiej delegacji ds. rozmów na temat umowy pokojowej z Rosją

W imieniu swojego rządu delegacja Rosyjskiej Federacyjnej Socjalistycznej Republiki Radzieckiej ds. rozmów z Litwą ogłasza, że przewidziane w tym artykule zobowiązanie Rosji do przestrzegania neutralności Litwy i uczestniczenia w gwarancjach zapewniających ten stan Rząd Robotniczo-Chłopski Rosyjskiej Federacyjnej Socjalistycznej Republiki Radzieckiej uzna tylko w tym przypadku, jeżeli Rząd Federacji Rosyjskiej weźmie udział w wypracowaniu warunków wymienionej neutralności Litwy.

A. Joffe, J. Marchlewski, L. Obolenski ${ }^{8}$.

6 Ibidem.

7 http://www3.lrs.lt/pls/inter_archyvas/dokpaieska_arch.showdoc_l?p_id=112582\&p_query=taikos $\%$ 20sutartis\&p_tr2=2 (03.01.2015).

$8 \quad$ LCVA, F. 383, Ap. 7, B. 77, s. 112. 
Tekst litewskiej delegacji w powyższej kwestii był taki:

Kopia

Państwowa Delegacja Litwy ds. rozmów na temat umowy pokojowej z Rosją

Odnośnie do artykułu V

Do delegacji Rosyjskiej Federacyjnej Socjalistycznej Republiki Radzieckiej ds. rozmów na temat umowy pokojowej z Litwą

W imieniu swojego rządu delegacja Litewskiej Republiki Demokratycznej ds. rozmów z Rosją ogłasza, że rząd Litwy przyjmuje do wiadomości oświadczenie delegacji Rosyjskiej Federacyjnej Socjalistycznej Republiki Radzieckiej ds. pokojowych rozmów z Litwą, że Rząd Robotniczo-Chłopski Rosyjskiej Federacyjnej Socjalistycznej Republiki Radzieckiej przyjmuje zobowiązanie do przestrzegania neutralności Litwy i uczestniczeniu w gwarancjach zapewniających ten stan tylko w tym przypadku, jeżeli Rząd Federacji Rosyjskiej weźmie udział w wypracowaniu warunków wymienionej neutralności Litwy.

Podpisy: T. Naruševičius, P. Klimas, S. Rozenbaumas, J. Vailokaitis, V. Račkauskas 9 .

Kolejne dokumenty w tej sprawie odnoszą się również do artykułu II i określają stanowiska obu stron:

R.S.F.R.R. Delegacja ds. rozmów na temat umowy pokojowej z Litwą 12 lipca 1920 roku Moskwa

Odnośnie do artykułu II

Do litewskiej delegacji ds. rozmów na temat umowy pokojowej z Rosją

Biorąc pod uwagę stan wojny między Rosją a Polską oraz okupację przez tę ostatnią części terytorium należącego na podstawie niniejszej umowy do Litwy, a także brak możliwości wstrzymania z powodu wojskowo-strategicznych wyliczeń działań wojennych armii rosyjskiej przeciwko Polsce na granicy z Litwą - osoby podpisujące ten dokument w imieniu Rządu Robotniczo-Chłopskiego Rosyjskiej Federacyjnej Socjalistycznej Republiki Radzieckiej oświadczają, że rząd rosyjski nie ma wątpliwości, że przekroczenie granicy litewskiej przez wojska rosyjskie i zajęcie przez nie części terytorium, które na mocy danej umowy należy do Republiki Litewskiej, w żadnym przypadku nie zostanie potraktowane przez rząd Litwy jako zerwanie niniejszej umowy pokojowej i jako nieprzyjazny akt wobec Litwy.

A. Joffe, J. Marchlewski, L. Obolenski ${ }^{10}$.

Odpowiedź strony litewskiej wobec tych kwestii była następująca:

Kopia

Państwowa Delegacja Litwy ds. rozmów na temat umowy pokojowej z Rosją

Odnośnie do artykułu V

Do delegacji Rosyjskiej Federacyjnej Socjalistycznej Republiki Radzieckiej ds. rozmów na temat umowy pokojowej z Litwą.

9 LCVA, F. 383, Ap. 7, B. 77, s. 113.

10 LCVA, F. 383, Ap. 7, B. 77, s. 114. 
Biorąc pod uwagę stan wojny między Rosją a Polską oraz okupację przez tę ostatnią części terytorium należącego na podstawie niniejszej umowy do Litwy, a także brak możliwości wstrzymania wojennych działań armii rosyjskich przeciwko Polsce na granicy z Litwą, osoby podpisujące ten dokument w imieniu rządu Litewskiej Republiki Demokratycznej oświadczają, że w żadnym przypadku nie będą traktować faktu przekroczenia litewskiej granicy przez wojska rosyjskie i zajęcia przez nie części terytorium, które na mocy niniejszej umowy należy do państwa litewskiego, jako zerwanie niniejszej umowy i jako nieprzyjazny akt wobec Litwy pod warunkiem, że po wygaśnięciu potrzeb wojskowo-strategicznych wojska rosyjskie zostaną wydalone ze wskazanego terytorium.

Podpisy: T. Naruševičius, P. Klimas, S. Rozenbaumas, J. Vailokaitis, V. Račkauskas ${ }^{11}$.

13 lipca 1920 r. strona litewska wystosowała depeszę do Ministerstwa Spraw Zagranicznych Rosji o następującej treści:

13 lipca 1920 roku (...) Panie Komisarzu, Jedenastego dnia tego miesiąca otrzymałem od naszej delegacji przebywającej w Moskwie wiadomość, że dwunastego dnia ma zostać podpisana umowa pokojowa między Litwą a Rosją. Stop. Władze Litwy wyrażają swoją radość i zadowolenie, że nareszcie między dwoma sąsiednimi państwami zostaną nawiązane dobrosąsiedzkie stosunki. Stop. Władze Litwy żywią nadzieję, że stosunki te będą jak najbardziej serdeczne. Stop. Z powodu wojny rosyjsko-polskiej wojska rosyjskie i litewskie posiadają wspólną linię kontaktową i w celu uniknięcia możliwych wspólnych starć władze Litwy mają zaszczyt zwrócić się z usilną prośbą do władz Rosji, aby wydały swojemu wojsku rozkaz zakazujący podążania do miejscowości zajętych przez wojska litewskie. Stop. Władze Litwy mają nadzieję, że władze Rosji uznają żądanie to za prawomocne i zasadne, gdyż dotyczy ono tylko terytorium Litwy, którego granice zostały już określone w umowie dwustronnej.

Dr Purickas Minister Spraw Zagranicznych ${ }^{12}$.

Odpowiedź władz Rosji na powyższy telegram nadeszła do Ministerstwo Spraw Zagranicznych Litwy 20 lipca 1920:

Otrzymano od delegacji Rosji w Rydze. Wręczono dr. Jauniusowi w dniu 20 lipca 1920 roku

Do Ministra Spraw Zagranicznych Litwy Pana Purickasa

$Z$ radością witamy wspólne działania wojsk litewskich i rosyjskich przeciwko polskim imperialistom, zagrażających litewskim i rosyjskim masom narodowym w decydowaniu o własnym losie. Obecnie sprawdziło się w praktyce, w jakim stopniu niezbędne było podpisanie umowy dwustronnej zezwalającej na czasowe zajęcie części terytorium Litwy przez wojska rosyjskie w celach strategicznych. 
Uważam za swój obowiązek jeszcze raz zapewnić, że nasza okupacja jest czasowa i że Rosja Radziecka nie zagraża niepodległości Litwy i samostanowieniu narodowemu pracującego narodu litewskiego.

Podpis: Cziczerin ${ }^{13}$.

Należy odnotować, że w drugiej połowie lipca na terenie Wileńszczyzny i Suwalszczyzny doszło zarówno do walk litewsko-polskich, jak i rosyjsko-polskich. Strona litewska z jednej strony wyraziła zgodę na przekroczenie swej granicy jednostkom armii radzieckiej i podejmowanie przez nie działań zbrojnych na swoim terytorium, z drugiej zaś - prowadziła akcje zbrojne przeciwko oddziałom polskim na terenach, które na mocy umowy litewsko-rosyjskiej zostały przyznane stronie litewskiej bez pytania o zdanie ludności zamieszkałej na tych obszarach ${ }^{14}$.

\section{Pozostałe artykuły umowy}

Kolejne artykuły omawianej umowy nie wywoływały tak dużych kontrowersji wśród obu stron, niemniej jednak warto przedstawić je w pewnym skrócie. W artykule VI Litwa i Rosja uzgodniły kwestie nadawania obywatelstwa osobom znajdujących się na terenie obu tych państw i przejmowania przez nie majątku. W artykule VII rozstrzygano problemy osób zesłanych i deklarowano stworzenie im możliwości powrotu do wcześniejszych miejsc zamieszkania ${ }^{15}$. Do tego punktu umowy delegacja litewska zgłosiła swe propozycje:

Kopia

Państwowa Delegacja Litwy ds. rozmów na temat umowy pokojowej z Rosją

Odnośnie do artykułu VII

Do delegacji Rosyjskiej Federacyjnej Socjalistycznej Republiki Radzieckiej ds. rozmów na temat umowy pokojowej z Litwą.

Biorąc pod uwagę fakt, że zarówno na Litwie, jak i w Rosji jest kategoria ludności zwana jeńcami wojennymi, toteż niżej podpisane osoby w imieniu Rządu Litewskiej Demokratycznej Republiki oświadczają, że ci ostatni $\mathrm{w}$ trakcie realizowania tego artykułu umowy zgodnie $\mathrm{z}$ wyżej wymienioną grupą ludności będą traktowani jako uchodźcy.

Podpisy: T. Naruševičius, P. Klimas, S. Rozenbaumas, J. Vailokaitis, V. Račkauskas ${ }^{16}$.

13 LCVA, F. 383, Ap. 7, B. 76, s. 51.

14 P. Łossowski, op. cit., s. 116-128.

15 Stenogram posiedzenia Sejmu Republiki Litewskiej z dnia 6 sierpnia 1920 roku, I sesji, 36 posiedzenia http://www3.lrs.lt/pls/inter_archyvas/dokpaieska_arch.showdoc_l?p_id=113702\&p_query=Li etuvos $\% 20 \mathrm{i} \% 20$ Rusijos $\% 20$ taikos $\% 20$ sutartis\&p tr2=2 (03.01.2015).

16 LCVA, F. 383, Ap. 7, B. 77, s. 120. 
W artykułach VIII, IX, X i XI strony dokonały wstępnej oceny wywiezionego majątku państwowego Litwy w zakresie różnych sfer gospodarki oraz zadeklarowały zrekompensowanie poniesionych strat na podstawie rozliczeń finansowych. $\mathrm{W}$ tym celu powołano różne komisje.

Artykuł XII był pewnym podsumowaniem wyżej wymienionych artykułów, gdyż określał wysokość kompensaty, jaką Rosja powinna wypłacić Litwie, wynoszącej sto tysięcy dziesięcin ${ }^{17}$ lasu (położonego na terytorium Rosji w pobliżu rzek lub dróg kolejowych z możliwością wycięcia w ciągu najbliższych 20 lat) oraz 3 mln złotych rubli. Wysokość kompensaty została ustalona przez stronę rosyjską. Sposób jej obliczania nie został wyjaśniony do dzisiaj - pewnym wskaźnikiem może służyć pierwsze zdanie tego artykułu, w którym Rosja konstatuje fakt, że zniszczenia wojenne na Litwie są bardzo wysokie, a jej mieszkańcy również ponieśli ogromne straty. Zgodnie z tym artykułem wypłata wyżej wymienionej kwoty miała nastąpić w półtoramiesięcznym terminie po ratyfikacji litewsko-rosyjskiej umowy pokojowej ${ }^{18}$. Ratyfikacja wyżej wymienionej umowy nastąpiła 6 sierpnia 1920 r. Również 6 sierpnia 1920 r. zostało podpisane porozumienie o przekazaniu Wilna i okolic stronie litewskiej.

Na podstawie kolejnego artykułu umowy pokojowej i jej ratyfikacji 16 października 1920 r. przez Sejm Litwy, Rosja dokonała wypłaty w wysokości $3 \mathrm{mln}$ rubli $\mathrm{w}$ złocie (monetami złotymi o nominale 5 rubli, co stanowiło 2,32 tony złota) ${ }^{19}$ jako kompensaty za poniesione straty nowo powstałemu państwu litewskiemu. Brak natomiast danych dotyczących przekazania stronie litewskiej lasu o powierzchni stu tysięcy dziesięcin.

W artykule XIII Litwa i Rosja zadeklarowały bardzo ścisłą, wręcz braterską współpracę gospodarczą - w handlu między obu państwami należy hołdować zasadzie najwyższej przychylności, stawka podatku i cła za tranzyt towarów miała być zerowa dla obu stron, wysokość opłaty za tranzyt towarów przez terytorium umawiającej się strony powinna być jak w przypadku miejscowych towarów, statki zaś obu stron miały dostęp na takich samych warunkach do portów obu państw.

Nawiązanie stosunków dyplomatycznych i konsularnych, które miały nastąpić po ratyfikacji umowy było przedmiotem artykułu XIV. Kolejny przepis poruszał kwestie amnestii $\mathrm{w}$ sprawach politycznych i dyscyplinarnych oraz

17 Dziesięcina - jednostka powierzchni ziemi w Rosji równa 1,0925 ha.

18 Stenogram posiedzenia Sejmu Republiki Litewskiej z dnia 6 sierpnia 1920 roku, I sesji, 36 posiedzenia http://www3.lrs.lt/pls/inter_archyvas/dokpaieska_arch.showdoc_l?p_id=113702\&p_query=Li etuvos\%20i\%20Rusijos\%20taikos\%20sutartis\&ptr2=2 (03.01.2015)

19 LCVA, F. 383, Ap. 7, B. 77, s. 90-107. Według podobnej zasady Estonia 2 lutego 1920 r. otrzymała od Rosji kompensatę w wysokości $15 \mathrm{mln}$ złotych rubli (co stanowiło 11,6 ton złota), Łotwa zaś - 11 sierpnia 4 mln złotych rubli. Więcej na ten temat: http://www.delfi.lt/news/daily/lithu ania/lietuviska-korta-uz-tris-milijonus-aukso-rubliu.d?id=12169113 (03.01.2015). 
sprawy związane z odbywaniem kary za przestępstwa kryminalne w państwie, którego obywatelem jest osoba pozbawiona wolności. Postanowienia końcowe tej umowy zostały zawarte $\mathrm{w}$ artykułach XVI-XIX ${ }^{20}$.

\section{Ratyfikacja umowy przez Sejm Litwy}

Umowa pokojowa między Litwą a Rosją została ratyfikowana przez Sejm Litwy na 36 posiedzeniu 6 sierpnia 1920 r. przy frekwencji 88 posłów z 112 ogólnej liczby posłów Sejmu. Ratyfikacyjna procedura polegała na trzykrotnym przedstawieniu umowy i przegłosowaniu każdego artykułu. Ostateczny wynik trzeciego głosowania był następujący: 85 głosów „za”, przy 3 głosach „wstrzymujących się”. Podczas omawiania umowy doszło do ostrych dyskusji i różnicy zdań. Pierwszy zabrał głos poseł Vladas Jurgutis, który jako referent Komisji Spraw Zagranicznych stwierdził, że Komisja większością głosów zdecydowała zgłosić umowę do ratyfikacji przez Sejm Litwy. W swym wystąpieniu odnotował fakt uznania niepodległości Litwy przez Rosję, co jest zawarte w umowie, oraz zauważył, że obie strony dzięki umowie uzyskają wiele korzyści politycznych i gospodarczych oraz rozległe terytoria. Odnotował przy tym, że sprawy związane z obecnością wojsk sowieckich na terytorium Litwy po ratyfikacji umowy przybiorą zapewne bardziej pomyślny obrót.

Jako drugi wypowiedział się w tej kwestii przedstawiciel socjaldemokratów Steponas Kairys, który krytycznie ocenił dyskutowaną umowę i zaproponował w imieniu frakcji socjaldemokratów, aby odłożyć jej ratyfikację. Główne zarzuty ze strony socjaldemokratów były następujące: pierwszy zarzut dotyczył obecności wojsk rosyjskich na terytorium Litwy i nieustalonej daty ich wycofania, drugi zaś był związany ze zwrotem mienia państwowego i prywatnego zagarniętego przez wojska Rosji carskiej. Zdaniem socjaldemokratów w umowie zbyt słabo zostały zaakcentowane również zobowiązania Rosji dotyczące zwrotu zagarniętego mienia ${ }^{21}$.

Kolejnym mówcą $\mathrm{w}$ tej sprawie był przedstawiciel bloku socjalistów ludowców i związku chłopskiego Mykolas Šleževičius, który w imieniu bloku podtrzymał wniosek o ratyfikacji umowy. Przewodnią myślą wystąpienia posła było stwierdzenie, że między Rosją a Litwą zostało już podpisane pewne

20 Stenogram posiedzenia Sejmu Republiki Litewskiej z dnia 6 sierpnia 1920 r., I sesji, 36 posiedzenia http://www3.lrs.lt/pls/inter_archyvas/dokpaieska_arch.showdoc_l?p_id=113702\&p_query=Li etuvos\%20i\%20Rusijos\%20taikos\%20sutartis\&p tr2=2 (03.01.2015).

21 Stenogram 36 posiedzenia Sejmu Ustawodawczego Litwy w dniu 6 sierpnia 1920 roku, http:// www3.lrs.lt/pls/inter_archyvas/dokpaieska_arch.showdoc_l?p_id=113702\&p_query=Lietuvos\%20 i\%20Rusijos\%20taikos\%20sutartis\&p_tr2=2 (03.01.2015). 
porozumienie o wycofaniu wojsk rosyjskich z zajętych terenów należących do Litwy. W trakcie wystąpienia również zaznaczył, że obecnie nie ma żadnej strategicznej potrzeby przebywania wojsk rosyjskich w Wilnie. Odnotował też pewne negatywne strony tej umowy oraz konstatował, że Litwa spóźniła się z podpisaniem umowy z Rosją, gdyż Estonia, która dokonała tego pięć miesięcy wcześniej, zapewniła sobie lepsze warunki. Poseł miał na myśli fakt, że Estonia otrzymała od Rosji 15 mln złotych rubli, Litwa zaś tylko 3 mln złotych rubli. Podsumowując, w imieniu swojego bloku odnotował, że po ratyfikacji umowy Litwa będzie miała prawną podstawę domagania się wycofania wojsk rosyjskich z zajętych terenów litewskich.

Przedstawiciel innej części frakcji socjaldemokratów Jeronimas Plečkaitis w swym długim wystąpieniu przekonywał zebranych o potrzebie natychmiastowej ratyfikacji umowy. Emocjonalnie stwierdził, że „Nasze jedyne szczęście, jeżeli Rosjanie wygrają wojnę z Polakami i jeżeli utrzyma się władza radziecka Rosjan”. Następnie podsumował: „Ze strony Rosji Radzieckiej ani obecnie, ani w przyszłości nie grozi naszej niepodległości żadne niebezpieczeństwo, dlatego też proponujemy ratyfikować umowę"22.

Przedstawiciel bloku chrześcijańskich demokratów Valdemaras Vytautas Čarneckis odnotował pozytywne i negatywne strony omawianej umowy. Do pozytywnych zaliczył fakt przyznania przez Rosję niepodległości Litwy, co oznaczało, zdaniem posła, zerwanie wszelkich więzi z państwem rosyjskim okupującym przez ponad wiek Litwę. Wysoko ocenił możliwości przyszłej współpracy gospodarczej z Rosją, której przesłanki widział w poszczególnych artykułach umowy. Za niewystarczające uznał zobowiązania Rosji dotyczące zwrotu zagrabionego mienia i wysokości kompensaty. Według posła straty, jakie poniosła Litwa podczas wojny, stanowiły $900 \mathrm{mln}$ rubli, dlatego też kompensata zaproponowana przez Rosję w wysokości $3 \mathrm{mln}$ rubli była niewystarczająca. Pomimo tych negatywnych aspektów poseł w imieniu bloku chrześcijańskich demokratów stwierdził, że umowę należy ratyfikować.

Następnie wystąpił premier Kazys Grinius, który w imieniu rządu zgłosił propozycję ratyfikacji umowy. Wymienił trzy pozytywne argumenty przemawiające za ratyfikacją: 1 . prawny dokument (umowa) potwierdzający niepodległość Litwy; 2. możliwość powrotu zesłańców, których (według oceny premiera) było w Rosji ok. 100 tys.; 3. zadawalająca powierzchnia terytorium, które na mocy tej umowy Litwa otrzyma. Poza tym premier stwierdził, że na skutek zniszczeń Litwa będzie mogła zwrócić jedynie część swego majątku. Jednakże premier podkreślił, że $\mathrm{w}$ obecnej sytuacji umowa pokojowa $\mathrm{z}$ Litwą jest dla Rosji bardzo ważna, gdyż zapewni to bezpieczeństwo prawego skrzydła wojsk rosyjskich. Na temat Wilna stwierdził, że ratyfikacja umowy dostarczy 
rządowi litewskiemu $\mathrm{w}$ rozmowach $\mathrm{z}$ Rosją istotnego argumentu przemawiającego za wycofaniem wojsk rosyjskich $\mathrm{z}$ tego regionu ${ }^{23}$.

Ostatnia w dyskusji wystąpiła Gabrielè Petkevičaitė-Bitė, posłanka frakcji chłopskiej, która stwierdziła, że najgorszy pokój jest lepszy od najlepszej wojny i zaapelowała o jak najszybsze zakończenie wojny. Po zakończeniu dyskusji głos zabrał poseł Valdemaras Vytautas Čarneckis, który w imieniu frakcji socjaldemokratów zgłosił wniosek dotyczący motywów głosowania. Stwierdził, że ponieważ duża część terytorium Litwy jest zajęta przez wojska rosyjskie, to część frakcji uważa ratyfikację tej umowy za przedwczesną i powstrzyma się od głosu.

Głosowanie nad ratyfikacją umowy podczas pierwszego czytania było następujące - wszyscy posłowie przegłosowali jednogłośnie z wyjątkiem czterech posłów z partii socjademokratycznej, którzy wstrzymali się, byli to: Kipras Bielinis, Valdemaras Vytautas Čarneckis, Stasys Digrys, Steponas Kairys. Podobny wynik głosowania był również podczas drugiego czytania umowy ${ }^{24}$.

Przed trzecim czytaniem ratyfikowanej umowy Sejm wysłuchał pozytywnych opinii trzech komisji - prawnej, spraw zagranicznych i obrony kraju. Zanim Sejm przystąpił do trzeciego czytania umowy wątpliwości wyraził w swym wystąpieniu poseł Vytautas Bičiūnas. Poseł stwierdził, że Litwa nie była i nie jest $\mathrm{w}$ stanie wojny z Rosją dlatego też sama nazwa "umowa pokojowa" powinna być odpowiednio wyjaśniona społeczeństwu Litwy. Niepokój posła budziły również przesłanki przyszłej współpracy gospodarczej z Rosją zawarte w umowie oraz nieratyfikowanie niniejszej umowy przez władze Rosji Radzieckiej.

$\mathrm{Na}$ zakończenie dyskusji przed trzecim czytaniem ratyfikowanej umowy wystąpił minister spraw zagranicznych Litwy dr Juozas Purickis. W swym przemówieniu odnotował trzy ważne argumenty, które według niego przemawiały za ratyfikacją umowy: 1 . wyzwolenie się spod Rosji i uznanie przez nią niepodległości Litwy; 2. zwrot majątku i możliwość powrotu na Litwę zesłanych mieszkańców; 3. złoty fundusz oceniony przez ministra jako nieduży, lecz zezwalający na wprowadzenie własnej waluty. Zaznaczył, że „siły zbrojne Litwy niewiele znaczą w porównaniu z Rosją", dlatego sugerował, że szansą Litwy są pokojowe rozwiązania. Poruszając temat obecności wojsk rosyjskich $\mathrm{w}$ Wilnie i w regionie, stwierdził, że tereny te otrzymają status terytorium Litwy dopiero po ratyfikacji, natomiast przed ratyfikacją jest to terytorium, do którego pretenduje Litwa. W zakończeniu zaakcentował, że wierzy, iż Rosjanie będą przestrzegać warunków umowy pokojowej i dlatego jest za tym, aby ją ratyfikować. 
Po wystąpieniu ministra Sejm Litwy przystąpił do trzeciego czytania pokojowej umowy i głosowania nad każdym artykułem, po czym odbyło się końcowe głosowanie $\mathrm{z}$ wynikiem jednomyślnym, z wyjątkiem trzech głosów wstrzymujących się 25 .

14 października 1920 r. w Moskwie nastąpiła wymiana protokołów ratyfikacyjnych między Litwa a Rosją zgodnie z artykułem XIX umowy pokojowej i w tym dniu umowa nabrała mocy prawnej ${ }^{26}$.

\section{Wnioski}

Umowa pokojowa między Litwą a Rosją bolszewicką z 12 lipca 1920 r. zawierała kilka niejawnych załączników podpisanych przez delegacje obu państw, stanowiących tajną część umowy. Najważniejsze z nich, które dotyczyły neutralności Litwy w toczącej się wojnie polsko-bolszewickiej, zostały podpisane przez stronę litewską i rosyjską. Strona litewska zapewniała stronie rosyjskiej wykorzystanie swojego terytorium do celów strategicznych podczas wojny polsko-bolszewickiej. Żaden z tych załączników nie był zgłoszony do ratyfikacji, mimo że dotyczyły one spraw bardzo ważnych. Z wypowiedzi posłów na Sejm Litwy, które odnosiły się do umowy pokojowej ratyfikowanej 6 sierpnia 1920 r., wynika, że posłom nie była znana treść niejawnych załączników tajnej części umowy dotyczących neutralności Litwy. Nie zgłosił tego również podczas swego wystąpienia ani premier, ani minister spraw zagranicznych. Z ubolewaniem należy odnotować fakt, że podczas ratyfikacyjnej procedury posłowie na Sejm Litwy jednoznacznie wypowiedzieli się za poparciem strony rosyjskiej w walce $\mathrm{z}$ wojskiem polskim, wykazując swą krótkowzroczność pogubili się w nowych realiach międzynarodowej sytuacji i całkowicie błędnie odczytali intencję strony bolszewickiej. Oddzielnym, niewyjaśnionym pytaniem jest ewidentne antypolskie zacietrzewienie znacznej części litewskich polityków latem 1920 r., które nie daje się wytłumaczyć walką o niepodległość młodego państwa.

\section{Bibliografia}

LCVA, F. 383 Ministerstwo Spraw Zagranicznych, Ap. 7 Działalność departamentu politycznego, B. 76 Dokumenty o stosunkach Litwa-Rosja.

\footnotetext{
25 Ibidem.

26 http://www3.lrs.lt/pls/inter_archyvas/dokpaieska_arch.showdoc_l?p_id=112582\&p_query=taikos $\% 20$ sutartis\&p_tr2=2 (03.01.2015).
} 
LCVA, F. 383 Ministerstwo Spraw Zagranicznych, Ap. 7 Działalność departamentu politycznego, B. 77 Dokumenty o negocjacjach Litwa-Rosja na temat umowy pokojowej.

Łossowski P., Konflikt polsko-litewski 1918-1920, Warszawa 1996.

Stenogram 36 posiedzenia Sejmu Ustawodawczego Litwy w dniu 6 sierpnia 1920 roku, http://www3.lrs.lt/pls/inter_archyvas/dokpaieska_arch.showdoc_l ?p_id=113702\&p_query=Lietuvos\%20i\%20Rusijos\%20taikos\%20sutartis\& p_tr2 $=2(03.01 .2015)$

Tekst pokojowej umowy między Republiką Demokratyczną Litwy a Rosyjską Federacyjną Socjalistyczną Radziecką Republiką z dnia 12 lipca 1920 roku http://www3.lrs.lt/pls/inter_archyvas/dokpaieska_arch.showdoc_l?p_id $=112582 \&$ p_query=taikos $\% 20$ sutartis\&p_tr2=2 (03.01.2015). 